\title{
Presentation of a Finlaison Medal to Adrian Waddingham, and Presentation of Honorary Fellowships to Dr Madhavi Bajekal and Professor Sir David Spiegelhalter
}

[Institute and Faculty of Actuaries, London, 4 May 2016]

The President (Ms F. J. Morrison, F.I.A.): Tonight we are celebrating the Finlaison Medallist Adrian Waddingham, and two new Honorary Fellows Dr Madhavi Bajekal and Professor Sir David Spiegelhalter.

The prestigious Finlaison Medal, which I had the pleasure of awarding to Adrian Waddingham, $\mathrm{CBE}$, at our recent awards dinner. The medal is awarded to those who have given exceptional service to the profession. Adrian was awarded it in recognition of the prominence that he gave to the actuarial profession, and particularly during his recent service as Sheriff in the City of London.

Many of you will know Adrian; but many of you may not. He has had his career as a consulting actuary, mainly with Barnett Waddingham.

Traditionally, Finlaison Medallists say a few words at a suitable meeting and Adrian will do that now.

Mr R. A. Waddingham, F.I.A.: President, members, guests, I have not yet recovered from the pleasant shock of being awarded the Finlaison Medal. Until then, the highlight of my life had been the award, in 2010, of pensions personality of the year.

During 45 years' membership of the profession - a frightening thought - I saw myself as a backbencher - literally. I remember the old wooden church benches in Staple Inn - not at all welcoming. But fellow actuaries have always been welcome, and it is a joy of our small profession that while we compete for business during the day, we enjoy time together in the evenings, both at Staple Inn and at the nearby Yorkshire Grey, the inn of choice back in those days.

President, I have an admission to make. I became an actuary only by accident. I graduated in 1971 with no job in mind but I did want to get to Liverpool. There was a girl there on whom I was rather sweet. Fortuitously, I stumbled upon an advertisement for training actuaries in the Liverpool head office of Duncan C Fraser \& Co and accepted that offer with alacrity. In that way I ended up with a career and a wife.

The senior partner in Liverpool was Past President Geoffrey Heywood and I took his advice to heart: never, never say no to any invitation, whether it is for a professional gathering or to a party. Geoffrey regarded both as important - and how right he was! I did not say no when invited to run Duncan C. Fraser's office in Kuala Lumpur in 1981. How good that our profession was, and still is, international in its outlook. 
The technical work in Malaysia was not demanding. Retirement funds paid out a lump sum at the age of 55, which was the age at which the colonial managers would retire, so no need to trouble myself with life expectancies.

But Malaysia did teach me about business. I was 6,000 miles away from head office. You even had to book your international telephone calls in those days, and there was nothing like watching the bank account, worrying lest fees and billing would not cover the monthly wage bill. Travel, too. Anything remotely pensions east of Europe was my bag. Best of all was 2 weeks in Fiji working for the national insurance scheme. "You must", I told them, as an eager young actuary, "drop this option at 55 instead of taking your full lump sum, taking a pension of one quarter of your fund every year for the balance of your life. There is nothing in local mortality to justify an annuity factor of four".

"Waddingham" the minister said "have you allowed for human nature? In the last 10 years only $7 \%$ of the retiring population have opted for the pension". Such was my hubris.

And I never forgot this lesson in human nature, and we are going to see this now with freedom and flexibility in our own pension schemes. I hope that when the dust settles on those reforms, those who do need a retirement income will not have cashed in their chips too soon. Plenty of work for actuaries there.

John Finlaison did not need to be taught annuity lessons. The eldest of four children born in the Highlands, and only 7 when his father died, Finlaison became Government Actuary and the very first President of the Institute of Actuaries, serving for 12 years.

Finlaison was interested in longevity tables, and in 1819 he wrote a controversial report demonstrating that the loss incurred by the government in granting life annuities at prices much below their value was horrendous. The report was suppressed by the government until 1824 . Then, as now, governments could not face expensive embarrassments. Finlaison's life tables were the first which showed the difference between male and female lives.

The first Finlaison Medal was awarded in 1985. The then President, Peter Moore, said: "I can think of no better person to be the first to receive this award". Rodney Barnett joined the Institute in 1932, qualified after war service in 1945, and, for the profession, worked on mortality, becoming Secretary of the Continuous Mortality Investigation Board.

Rodney had retired before Barnett Waddingham was formed, but he followed its growth with interest.

In 1985, my next foreign posting was London; Lancashire being the centre of the world. I am currently President of the Association of Lancastrians in London - something else to which I could not say no.

In London, in 1979, Geoffrey Heywood and Max Lander helped form the 91st Livery Company of the City of London, the Worshipful Company of Actuaries. Again, I said yes when invited to join. I became Master in 2009. The City, its ceremonies and its institutions, are quite well known, but less so the millions spent by the City, not from rates - all the rates go to the exchequer - millions spent funding charities, schools, academies, open spaces, arts, museums and even the Old Bailey. 
In addition, there are now 110 livery companies. Collectively, they give to charity over $£ 40$ million every year. The Company of Actuaries plays its part, giving almost $£ 200,000$ per annum, much of it to mathematics education. We are pulling our weight.

Having been Master Actuary and seen the City from the inside, I stood for election as one of its two Sheriffs in 2013. Angela and I lived in the Old Bailey for a year. Busy, but busy doing nice things: hosting lunch for the judges every day, dinner every night, promoting the City and financial services. I was pleased to be able to host the Institute, the Association of Consulting Actuaries and the International Association of Consulting Actuaries at the Old Bailey - and I let most of them out again!

I had hoped that my shrieval responsibility to manage executions would allow me to bring life expectancy tables back into line. But, sadly, their lordships no longer don the black cap.

There is still, in the Old Bailey, the dead man's walk: the route to the gallows. This is a series of reducing doorways, cruelly designed, I would say to guests, to emphasise that this was not a journey from which they would return. But, afterwards, an actuary wrote to me and said perhaps this was not the cruelty I had described. He said the reducing doorways made a perspective that made their last walk look rather longer than it really was. Who knows?

I consider myself blessed to have belonged to a profession that has grown steadily and diversified and in many, many senses of that word - over the 45 years that I have known it. My rush to Liverpool in 1971 served me well; I kept my career and I kept my wife. I love them both.

I was pleased to promote the actuarial profession in the Square Mile but I could only do this because of the support of my firm and in particular my co-founding and senior partner, Immediate Past President Nick Salter. While I was lunching and dining and travelling, Nick was working hard, running both the Institute and the shop - an allocation of roles that suited me rather well. Thank you, Nick. I would share this award with you.

President, Members of Council, thank you so much for this award. I will continue to support the profession in any way I can but perhaps not for another 45 years. Thank you.

The President: One of the great things about being President is introducing new members to the profession. I am privileged tonight to be able to present two Honorary Fellowships. Our Honorary Fellows bring a huge amount of expertise to the Institute and Faculty of Actuaries (IFoA) and the actuarial profession more generally.

The first Honorary Fellowship is to Dr Madhavi Bajekal. Madhavi is Senior Research Fellow at University College London's (UCL) Institute of Epidemiology and Health Care. She leads a research team made up of epidemiologists, statisticians, clinicians and "big data" scientists. The team is investigating the drivers of recent improvements in mortality, morbidity and longevity in the UK and, in particular, looking how these vary by socio-economic circumstances.

Her research is supported by Legal \& General, where she is Principal Scientist in the Longevity Science Team and a Member of the Longevity Science Panel. During her career she has held many senior management roles in the UK civil service, in academia and in industry. Before joining UCL, she was Deputy Divisional Director for Social and Healthcare Analysis at the Office for National Statistics. 
She chaired Eurostat's "Partnership in Health" project. What this project was about was an EU-wide effort to harmonise concepts and methods for the measurement of health, morbidity and mortality to generate comparative statistics for EU policy development.

Madhavi is a Fellow of the Royal Statistical Society. For the Institute and Faculty she has been a long-standing member of our Mortality Research Steering Committee and led and participated in many of our events. Madhavi has published over 50 peer-reviewed papers, which I think beats Adrian and me, and she has appeared in the British Actuarial Journal.

You will be able to tell from her CV that she has many contacts in academia, government and industry, and those have been immensely useful to us at the Institute and Faculty, and we very much look forward to working even more closely with you, Madhavi, in the future.

Dr M. Bajekal, H.F.I.A.: Thank you, President. This is a very great honour and I am almost overwhelmed. I do not know what to say, especially listening to that $\mathrm{CV}$, which you have just read out. It did not sound like me at all.

I should like to thank first Peter Banthorpe and Brian Ridsdale for nominating me and the entire Mortality Research Steering Committee for their generous support and unfailing enthusiasm about my contribution, asking me to engage actively with the profession. I should particularly like to thank Joseph Lu and Professor Rosalind Raine for setting up the collaboration between UCL and Legal \& General almost a decade ago. This model of open collaboration between industry and academia has nurtured what I call intellectual diversity which I think chimes very well with the recently launched IFoA strategy on diversity as well as with the Research and Thought Leadership Committee's aims of bringing together academia and industry.

We now have, as Fiona said, a very diverse professional group working together. That includes actuaries like my colleague here, Mei Chan, clinicians, data scientists, modellers, all working together to solve the same problems, very often outside their comfort zones. So, it is quite hairy at moments to get them all together on the same topic and keep them focussed. But it is intellectually very stimulating.

Our research has generated new evidence and scientific knowledge on the changing relationship between social inequalities, lifestyles and health care when examining the risk of mortality, particularly for heart disease.

We have now expanded and are looking at big data, or linked electronic health records, to look at how having two or more diseases concurrently affect your longevity, especially in older ages where multi-morbidity is the norm.

For me, personally, my involvement with the IFoA and the industry has been an incredibly rewarding experience. I encourage all of you to volunteer for many of their groups, and I should also like to say that I think that this model of industry/academia collaboration should be taken on by more people. It should become a template for the future. The problems of living longer in our society are complex problems that no one profession can solve. Thank you all very much.

The President: I should have said in my introduction that outside you might have seen one of our longevity bulletins in which the fourth article is by Madhavi. 
So to our third celebration tonight, and our second Honorary Fellow of the evening, and nonetheless for that: Professor Sir David Spiegelhalter. David is Winton Professor for the Public Understanding of Risk and Professor of Biostatistics at the University of Cambridge. His background is in medical statistics, and particularly the use of Bayesian methods in clinical trials, health technology assessment and drug safety.

In his post he leads a small team that attempts to improve the way in which the quantitative aspects of risk and uncertainty are discussed in society.

He works closely with the Millennium Mathematics Project in Cambridge in trying to develop exciting treatment of probability and risk in mathematics education.

David has written over 200 refereed publications - which is definitely more than Adrian and me! He is co-author of six text books, including The Norm Chronicles as well as author of Sex by Numbers. There are some of his books on the stand in the foyer.

David is a Fellow of Churchill College, Cambridge. He is an Honorary Fellow of the Institute of Risk Management, an Honorary Fellow of the Royal College of Physicians and he was elected Fellow of the Royal Society in 2005. For services to medical statistics he was awarded an OBE in 2006 and a knighthood in 2014.

Prof Sir D. Spiegelhalter, H.F.I.A.: President, thank you so much for the nice speech and, of course, for the award of this Honorary Fellowship, which is wonderful. I am very excited about it.

I am going to be the next President of the Royal Statistical Society for 2017-2018. One aspect is that we really look forward to closer connections between the IFoA and the RSS in the future. It is going to be fun. 